\title{
Glutathione improves the prognosis of intrauterine growth restriction via downregulated hepatic and renal TNFa expression in Wistar rats
}

\section{Glutatyon Wistar sıçanlarında hepatik ve renal TNFa ekspresyonunun downregülasyonuyla intrauterin gelişme geriliğinin prognozunu olumlu etkiliyor}

${ }^{1 *}$ Alese $\mathrm{MO},{ }^{2}$ Shallie $\mathrm{PD},{ }^{1}$ Bamisi OD

${ }^{1}$ Department of Anatomy, College of Medicine, Ekiti State University, Ado-Ekiti, Nigeria

${ }^{2}$ Department of Anatomy, College of Medicine, Olabisi Onabanjo University, Ago-Iwoye, Nigeria.

Corresponding author: Alese MO, MD, Department of Anatomy, College of Medicine, Ekiti State University, Ado-Ekiti, Nigeria.

E-mail: margaret.alese@eksu.edu.ng

Received/Accepted: January 13, 2021 / December 27, 2021

Conflict of interest: There is not a conflict of interest.

\section{SUMMARY}

Objective: Oxidative stress is requisite for the development of IUGR, with subsequent manifestation in the reduced levels of antioxidants enzymes. Glutathione protects against free radical-mediated injury, therefore we elucidated on its role in protecting against oxidative stress-induced consequences of IUGR.

In order to improve the prognosis of IUGR in affected infants, we investigated the protective role of glutathione in rats exposed to IUGR.

Method: Ten female Sprague-Dawley rats were mated overnight. The pregnant rats were divided into 2 groups of 5 rats each. From gestational day 9 until parturition, group A received normal saline while group B received $50 \mathrm{mg} / \mathrm{kg}$ daily of L-NAME. Pups from group A were allowed free access to food and water, while group B pups were randomly assigned into 3 groups; G1 pups were left untreated; $1.5 \mathrm{~g} / \mathrm{kg}$ of gluthatione was administered to G2 pups from PND 4-10 and G3 pups from PND 25-31. We measured the body weight of rats; immunolocalized and further quantified TNF $\alpha$ expression in the hepatic and renal tissues.

Results: Postnatal GSH administration increased body weight in treated groups exposed to IUGR more significantly from days 4-10 as opposed to days 25-31. IUGR resulted in a significant increase in the $\mathrm{TNF} \alpha$ immunoreactivity in the hepatic and renal tissues of the untreated group of rats when compared with the control and treated groups. GSH significantly reduced TNF $\alpha$ immunoreactivity in the kidney and liver of the treated groups, especially the days 4-10.

Conclusions: Oral GSH administration regulates the inflammatory response in IUGR at the early neonatal period.

Keywords: IUGR, glutathione, TNF $\alpha$, oxidative stress, inflammation.

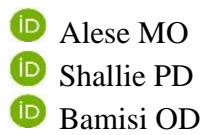

ORCID IDs of the authors: A.M.O. 0000-0002-8582-5348 S.P.D. 0000-0001-9910-3584 B.O.D. 0000-0001-7625-2456

\section{ÖZET}


IUGR gelişmiș infantlarda prognozu iyileștirmek için, IUGR geliştirilen sıçanlarda glutatyonun koruyuculuğu araştırıldı, Yöntem: On adet diși Spreague-Dawley sıçanı bir gece boyunca çiftleștirildi. Gebe sıçan her birinde 5 sıçan olacak şekilde 2 gruba ayrıldı. Gebeliğin 9. gününden doğuma kadar A grubuna normal salin verilirken, B grubuna günde 50 $\mathrm{mg} / \mathrm{kg}$ L-NAME verildi. A grubundaki yavruların yiyecek ve suya serbestçe erişimlerine izin verilirken, B grubu yavrular rastgele 3 gruba ayrıld1; G1 yavruları tedavi edilmeden bırakıld1; G2 yavrularına postnatal 4 - 10. günler arasında ,G3 yavrularına postnatal 25-31. günler arasında $1.5 \mathrm{~g} / \mathrm{kg}$ glutatyon verildi. Sıçanların vücut ağırlığı ölçüldü; hepatik ve renal dokularda TNF $\alpha$ ekspresyonu immünlokalize edildi ve ayrıca ölçüldü.

Bulgular: Doğum sonrası GSH uygulaması, IUGR gelişen sıçanlarda 25-31. günlerde verilen tedavinin aksine 4-10. günlerde verilen tedavide vücut ağırlığını daha fazla arttırdı. IUGR, kontrol ve tedavi edilen gruplarla karşılaştırıldığında, tedavi edilmeyen sıçan grubunun karaciğer ve böbrek dokularında TNF $\alpha$ immünoreaktivitesinde önemli bir artışa neden oldu. GSH, tedavi edilen grupların böbrek ve karaciğerinde, özellikle 4-10. günlerde TNFa immünoreaktivitesini önemli ölçüde azaltt1.

Sonuç: Oral GSH uygulaması, erken neonatal dönemde IUGR'deki inflamatuar yanıtı düzenlemektedir. Anahtar sözcükler: IUGR, glutatyon, TNFa, oksidatif stres

\section{INTRODUCTION}

Intrauterine growth restriction (IUGR) is a consequential complication of pregnancy characterized by a remarkable reduction in fetal growth and/or its organs during gestation when compared to the expected genetic growth potential 1 . Fetuses exposed to IUGR are characterized as small for their gestational age ${ }^{2}$. IUGR is a factor associated with stillbirth, heightened risk of premature delivery, increased premature neonate's morbidity, hypercholesterolemia, blood coagulation, cardiovascular disease and Type 2 diabetes in adult life ${ }^{3,4,5,6}$. Fetal undernutrition results in fetuses with impaired growth leading to a heightened possibility of adverse short and long term consequences ${ }^{7}$. Physiological functions can be influenced postnatally by minute changes in cell composition of tissues induced by conditions that are suboptimal in intrauterine life ${ }^{8}$. There is increasing evidence suggesting that the liver and kidney are affected by IUGR following unfavorable in utero exposure. IUGR not only affects the body to kidney ratio but also reduces the number of nephrons, which leads to a reduced surface for glomerular filtration and ultimately resulting in glomerular hypertrophy which leads to impairment of renal function ${ }^{9,10,11}$. Studies have shown that fetuses exposed to IUGR display altered gene expression that encodes enzymes involved with the production of hepatic energy, hepatic oxidative phosphorylation reduction and affectation of the transport of hepatic glucose ${ }^{12,13 \text {, }}$ ${ }^{14}$. An increasing body of experimental data has been able to demonstrate oxidative stress as a key player in the development of IUGR, with subsequent manifestation in the reduced levels of antioxidants enzymes in IUGR neonates ${ }^{15,16,17}$.

Glutathione (GSH) is the most abounding nonenzymatic antioxidant with low molecular weight and a predominant distribution inside the cell. It serves varieties of functions which includes scavenging of reactive oxygen/nitrogen species, acting as a detoxifying agent, storage of intracellular cysteine and modulation of the activity of proteins via reversible protein glutathionylation, influencing cell cycle progression, cell death and transcription factor activity and signaling signaling $18,19,20$. Its depletion leads to increased oxidative stress, which alters the endogenous enzymes and proteins which can lead to impaired cellular function, ultimately playing a role in the onset of several diseases $21,22,23$. Oral supplementation of GSH helps improve its status in circulation while lowering inflammation ${ }^{24,25}$.

In this study, we investigate the protective role of glutathione against inflammation in the liver and kidney of rats exposed to IUGR, in the search for improvement in the prognosis of IUGR infants.

\section{MATERIAL AND METHODS}

\section{Experimental animals}

Following instutional ethical approval (OOU/BMSREC/18/0045), 10 female SpragueDawley rats, weighing between 130-150 g were used for the experiment. The animals were obtained from Peter's Farm (Nig.) Enterprises in Badagry; housed in plastic cages in the animal holding of the Department of Anatomy, Olabisi Onabanjo University, Ago-Iwoye, Nigeria under standard laboratory conditions and fed rat chow (Boar feed, Ikene) with water ad libitum. They were left to acclimatize for two weeks before the commencement of the experiment.

\section{Animal Care and Management}

Following confirmation of mating by the visualization of spermatozoa in a vaginal smear, the pregnant rats were divided into 2 groups (A \& B) containing 5 rats each. Group A served as the 
control while B served as the treatment group. Group A received normal saline orally from gestational day 9 until parturition, while Group B received $50 \mathrm{mg} / \mathrm{kg}$ daily of L-NAME from gestational day 9 until parturition.

The rats in Groups A and B were allowed to litter; after delivery, pups confirmed with IUGR in group B were recruited for the study. Pups from group A were allowed access to food and water ad libitum, while pups from group B were randomly assigned into 3 groups; G1 pups were not treated with glutathione; G2 litters were administered gluthatione at a dose of $1.5 \mathrm{~g} / \mathrm{kg} /$ day intraperitoneally from post natal day 4-10 (PND 410); G3 pups were administered gluthatione from PND 25-31 26, 27, 28 .

All pups were weighed daily during the period of administation to monitor the effect of the treatment on body weight.

\section{Animal sacrifice and excision of organs}

At the end of the experimental period, following administration of sodium pentobarbital $(100 \mathrm{mg} / \mathrm{kg}$ body weight), the rats were transcardially perfused with PBS followed by ice-cold 4\% paraformaldehyde in PBS. The liver and kidney tissues were excised after a mid-line abdominal incision and fixed in neutral buffered formalin; then processed routinely for paraffin embedding with LEICA ASP 200S and embedded in paraffin using LEICA EG1 $150 \mathrm{H}$ embedding machine. Thin sections $(3 \mu \mathrm{m})$ were cut on a rotary microtome (Leica RM 2135, Germany) and mounted onto poly-L-lysine coated glass slides (X-tra Adhesive, Leica Microsysytems, Germany).

\section{Immunohistochemistry and staining for immunoreactivity}

The sections were dewaxed in xylene and rehydrated before incubation in a Target Retrieval Solution (Dako, Denmark). For endogenous peroxidase blocking, sections were incubated in 3\% hydrogen peroxide for $10 \mathrm{~min}$; then well rinsed with PBS and incubated with normal goat serum for 30 minutes. Thereafter, incubation in anti$\mathrm{TNF} \alpha$ polyclonal antibody (Elabscience, USA) was done for $30 \mathrm{~min}$ with a dilution of 1:50 at room temperature. Sections were then rinsed with wash buffer and incubated with anti-rabbit secondary antibodies (HRP) (Dako, Denmark) for $20 \mathrm{~min}$ at room temperature. The reaction was visualised within $10 \mathrm{~min}$ with diamino-benzidine (Elabscience, USA) and the nuclei counterstained with Mayer's haematoxylin. Primary antibody was replaced by wash buffer for negative controls.
Morphometric evaluation of the immunostained sections

The stained sections were examined and photomicrographs taken under OMAX 40X2000X light microscope. Image J, a public domain software sponsored by the National Institute of Health (USA), was used to analyse and quantify photomicrographs. Using the immunoratio plugin, the areas of DAB brown staining were automatically selected from haematoxylin counterstained blue nuclear area. The plugin generates the percentage of DAB area (positive immunoreactivity) to the whole nuclear area.

\section{Statistical Analyses}

Results were expressed as means \pm SEM. One-way ANOVA was used for comparative analysis of the data between treated and non-treated groups of rats, followed by Bonferroni test for multiple comparison. Statistical significance was set at $\mathrm{p}<$ 0.05. GraphPad Prism version 5.00 for Windows (GraphPad Software, USA) was used for analysis.

\section{RESULTS}

\section{Body weight}

At birth, there was a significant reduction $(\mathrm{p}<0.0001)$ in the mean body weight in the IUGR group $(4.5 \pm 0.02 \mathrm{~g})$ compared with the control $(5.0 \pm 0.05 \mathrm{~g})$ (Figure 1). As seen in figure 2, on day 4 of the experimental period, the body weight differed across the study groups $(\mathrm{p}=0.0112)$. At the end of the experimental period (day 31), there was a significant reduction $(\mathrm{p}<0.001)$ in the body weights of the rats in G1 $(28 \pm 0.52 \mathrm{~g}), \mathrm{G} 2(32 \pm 0.29$ $\mathrm{g}), \mathrm{G} 3(30 \pm 0.36 \mathrm{~g})$ when compared with the control group $(34 \pm 0.28)$ respectively. Also, there was a significant increase in body weight in G2 and G3 and rats compared with $\mathrm{G} 1(\mathrm{p}<0.001)$; a significant reduction was observed in $\mathrm{G} 3$ rats compared with $\mathrm{G} 2$ ( $\mathrm{p}<0.001)$.

\section{Immunolocalization and morphometric image analysis of TNF $\alpha$ in the liver}

A variable degree of immunoreactivity of TNF $\alpha$ was observed in the parenchymal cells across the groups (Figure 3A). Positive immunostaining of the parenchymal cells was seen in the G1 and G3 groups while there was weak staining in the control and G2 groups. The mean percentage immunoreactivity of TNF $\alpha$ within the control, G1, G2 and G3 groups were $8.4 \pm 0.43 \%, 64 \pm 3.0 \%$, $12 \pm 0.81$ and $28 \pm 3.8 \%$ respectively. There was a significant increase in the TNF $\alpha$ immunoreactivity in the hepatic tissues of the untreated IUGR group of rats when compared with the control (Figure $3 B)$. The immunoreactivity in the G2 group was 
increased when compared with the control albeit not statistically significant $(\mathrm{p}>0.0001)$. While, a significant reduction was seen in both G2 and G3 groups when compared with G1 $(\mathrm{p}<0.0001)$, a significant increase was observed in the G3 group compared with G2 (p<0.001).

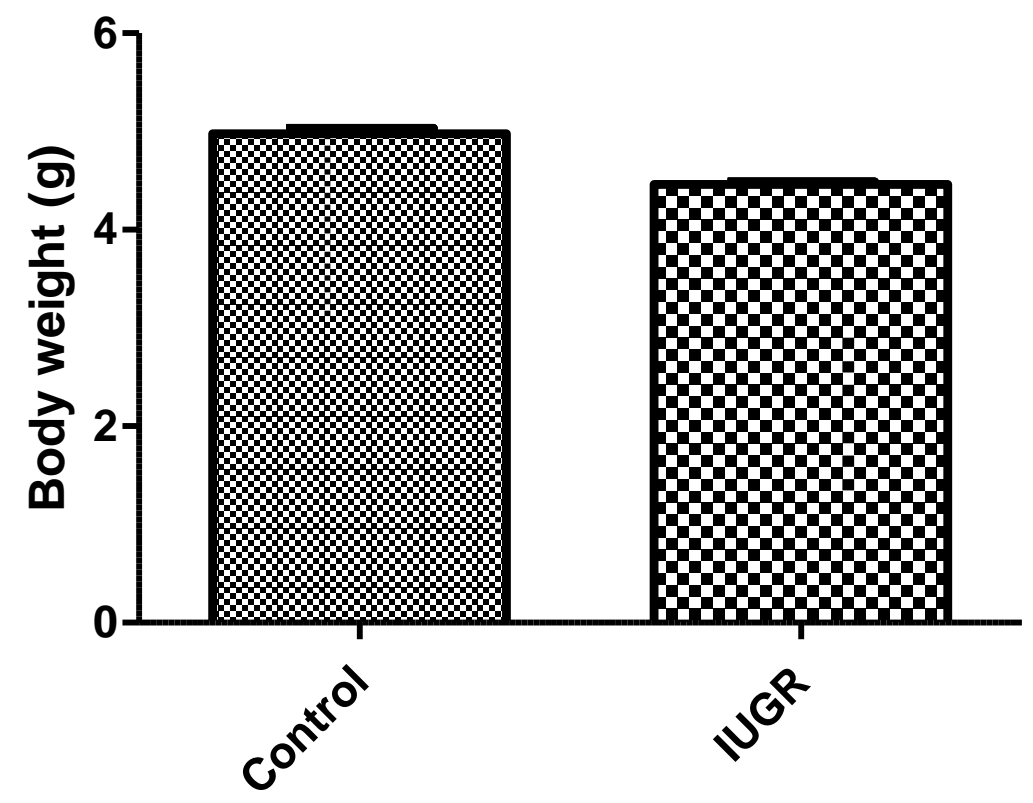

Figure 1: Body weight of control and experimental groups of rats at birth. Values are presented as means \pm standard deviation (SD). Statistical significance set at * $\mathrm{p}<0.05$.

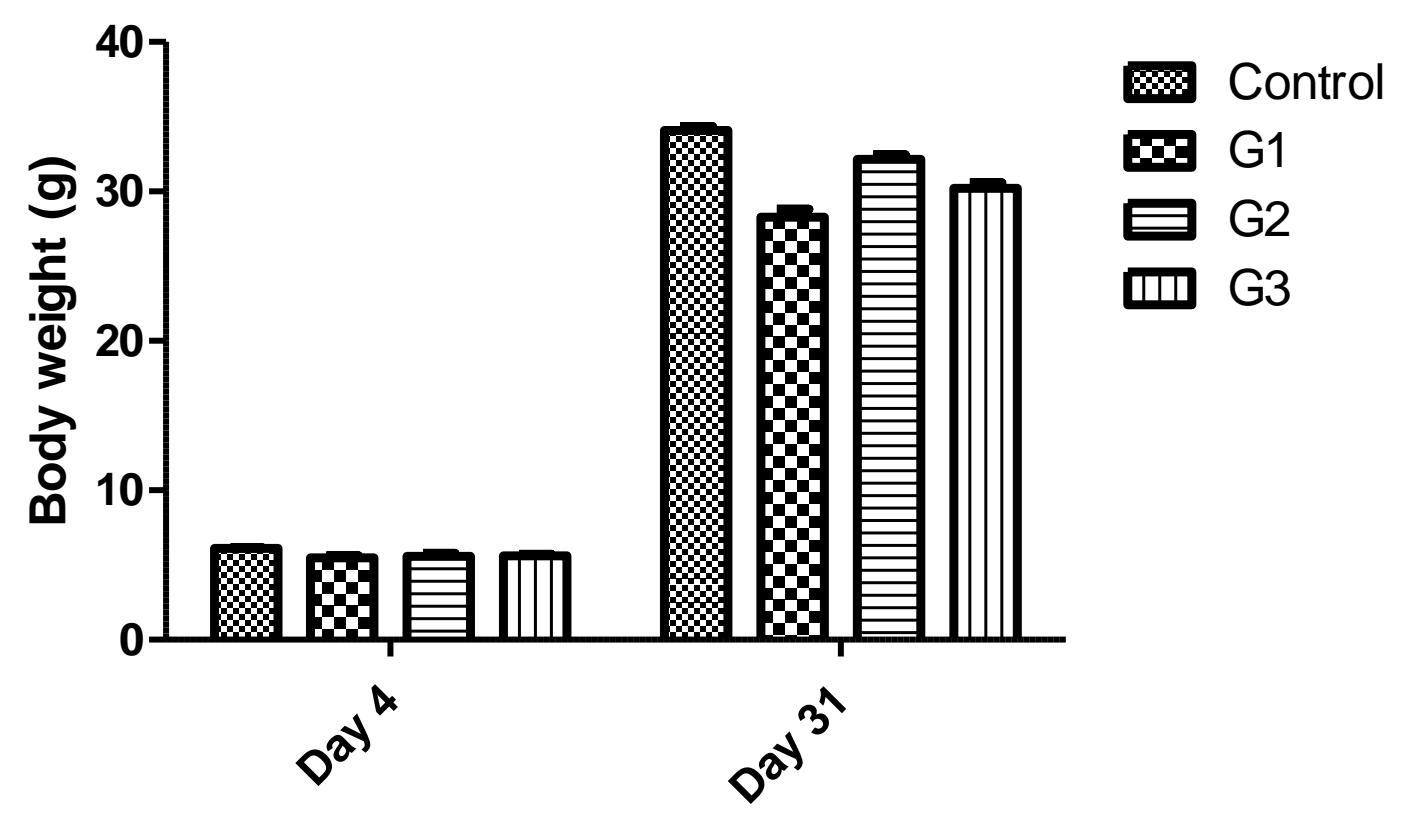

Figure 2: Body weight of control and experimental groups of rats throughout the treatment period. Values are presented as means \pm standard deviation (SD). Statistical significance set at $* p<0.05$. 


\section{Immunolocalization and morphometric image analysis of TNF $\alpha$ in the kidneys}

Immunoreactivity of TNF $\alpha$ was noted across the study groups (Figure 4 A). While a strong immunoreactivity was observed in the glomerulus and renal tubules in the G1 group, the G3 group showed reactivity in the renal tubules while there was a weak staining in both the control and G2 groups. Quantitative analysis showed that there was a significant increase in the mean TNF $\alpha$ immunoreactivity in the renal tissues of the untreated IUGR group of rats $(37 \pm 3.3 \%)$ when compared with the control (3.6 $\pm 0.54 \%)$. Although the mean immunoreactivity in the G2 group $(7.9 \pm 0.54 \%)$ was increased when compared with the control, it was not statistically significant ( $>0.0001)$. Also, there was a significant reduction in both G2 and G3 (18 $\pm 1.4 \%)$ groups when compared with G1 $(\mathrm{p}<0.0001)$; a significant increase was observed in the G3 group compared with $\mathrm{G} 2(\mathrm{p}<0.01)$ (Figure 4B).
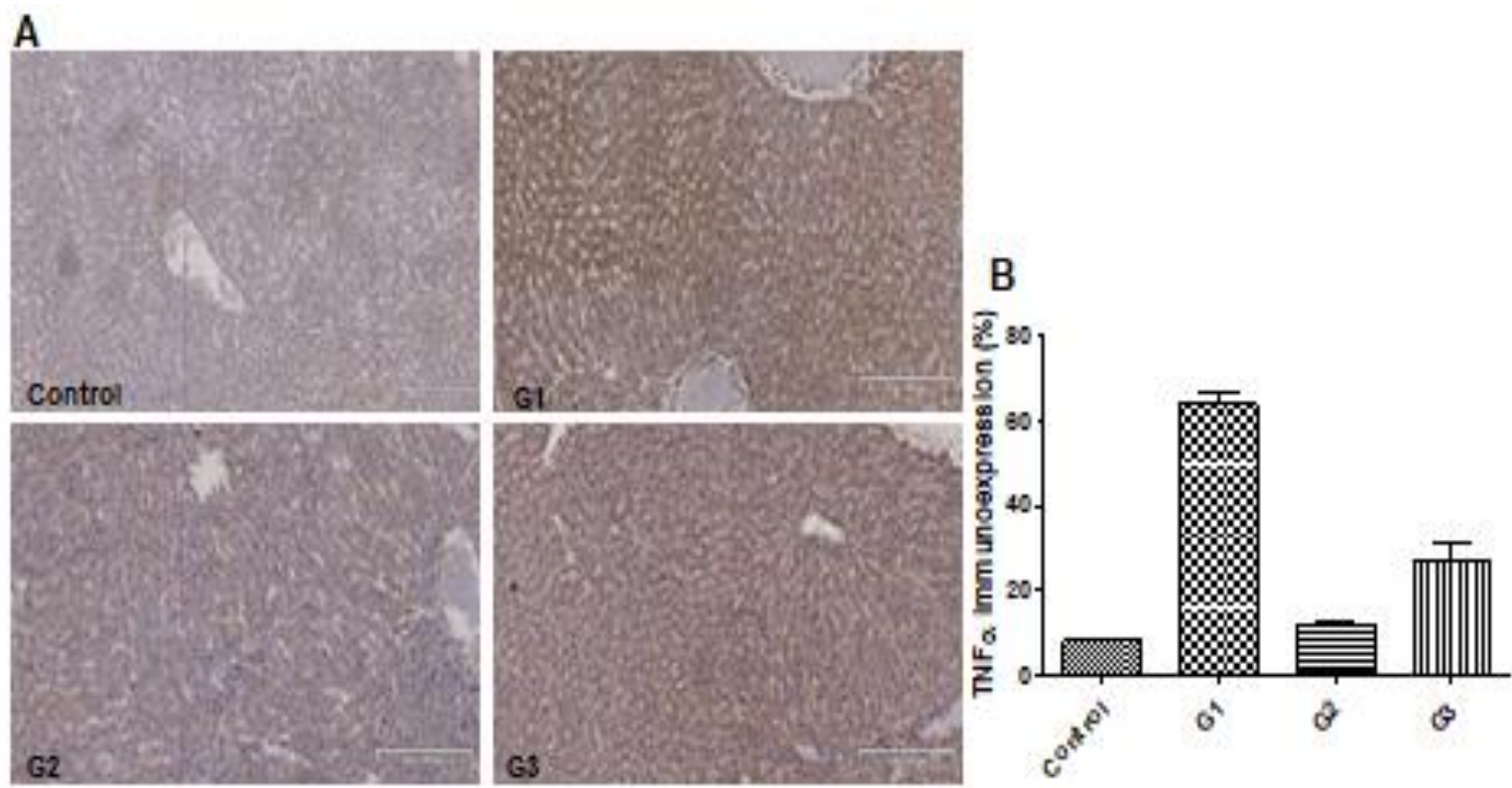

Figure 3: A: Photomicrographs of liver tissue sections analyzed by IHC for TNF $\alpha$ in experimental rats; B: Morphometric Image Analysis of immunoreactivity of TNF $\alpha$ in the hepatic tissues. 
A
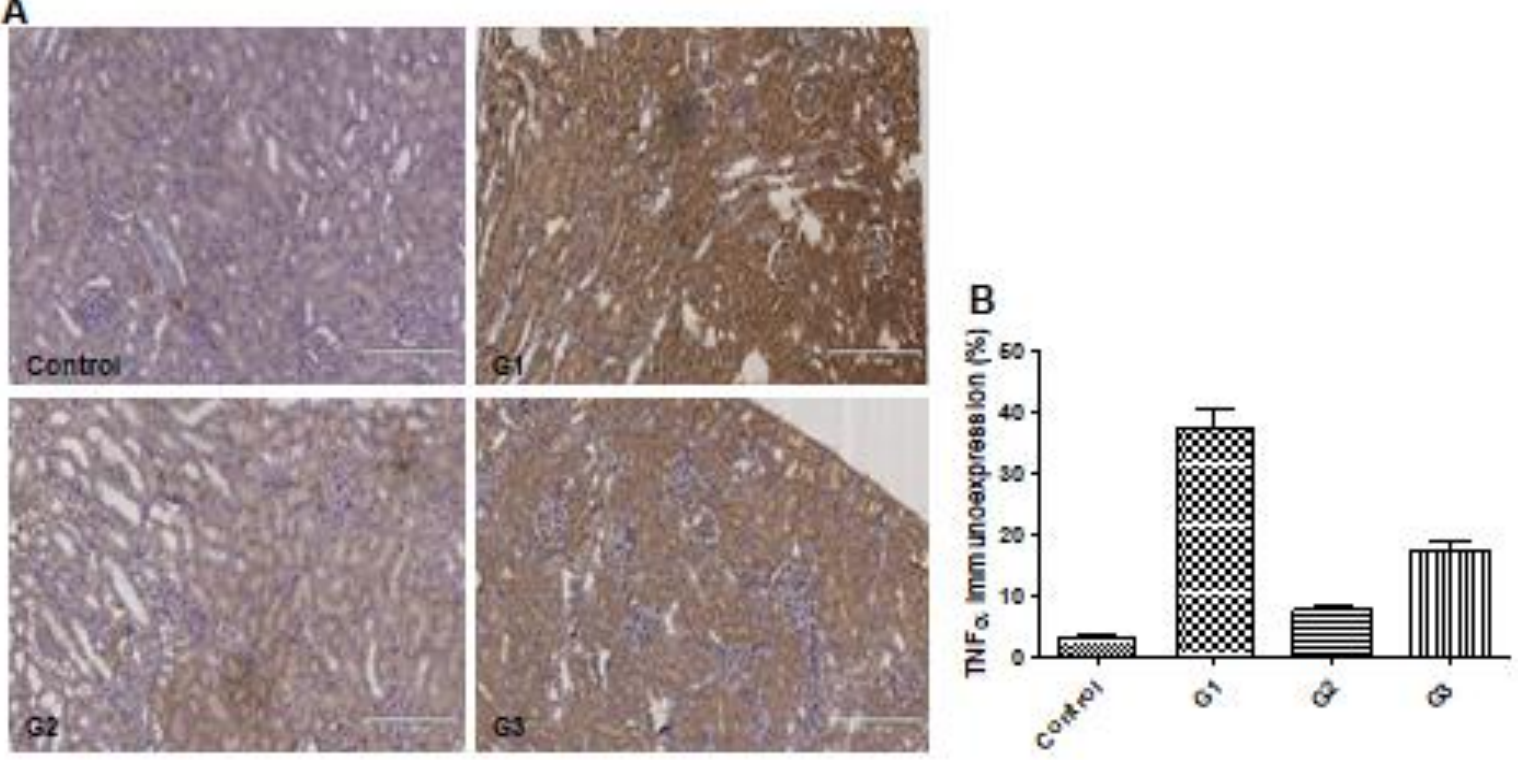

Figure 4: A: Photomicrographs of kidney tissue sections analyzed by IHC for TNF $\alpha$ in experimental rats; B: Morphometric Image Analysis of immunoreactivity of TNF $\alpha$ in the renal tissues.

\section{DISCUSSION}

Intrauterine growth restriction results from the failure of progression in the growth of a developing fetus during intrauterine life ${ }^{1}$. Neonates exposed to an IUGR environment have lower birth weight than normal neonates, mainly due to fetal undernutrition which is a consequence of placental insufficiency. Furthermore, it has several detrimental effects on growth and development in infancy and childhood which could also span over a lifetime ${ }^{29,30}$.

In this present study, we used an IUGR model of rats administered $50 \mathrm{mg} / \mathrm{kg}$ daily of L-NAME from gestational day 9 until parturition; this caused a reduction in body weight gain in rats exposed to IUGR during intrauterine life compared with those who had a normal intrauterine milieu. In line with this, other studies have been able to show that IUGR results in growth retardation both for the fetus and neonates ${ }^{31}$. However, postnatal administration of GSH increased body weight in treated groups. This increase in body weight was more significant in rats administered GSH from days 4-10 as opposed to days 25-31. This significant difference between the two-time points of administration underscores the importance of early intervention in neonates with IUGR environment during intrauterine life. Xia and $\mathrm{Wu}^{32}$ administered a dietary supplementation of GSH on Pacific white shrimp which caused a significant increase in growth performance indices including body weight gain compared with the group administered GSH free diet; this is in agreement with our study result. The action of GSH may be due to its beneficial effects on the liver function which may account for its growth-promoting effects on the body ${ }^{33}$.

Oxidative stress is as an imbalance between the production of reactive oxygen species (ROS) and antioxidants, which can lead to chronic inflammation ${ }^{34}$. Various stimuli which could induce inflammation such as an imbalance in ROS/RNS production have been reported to induce the inflammatory process, ultimately leading to the synthesis of proinflammatory cytokines. The activation of TNF- $\alpha$ has been documented to play a critical role in the inflammatory process resulting in several chronic diseases like diabetes and cardiovascular diseases which have been linked to IUGR in later years ${ }^{35}$. In our study, IUGR resulted in a significant increase in the TNF $\alpha$ immunoreactivity in the hepatic and renal tissues of the untreated IUGR group of rats when compared with the control and GSH treated groups. This is due to intrauterine programming in which diversion of limited nutrients typical of IUGR occurs to the brain at the detriment of organs such as the liver and kidney which may become prone to structural and physiologic alterations ${ }^{8,36}$.

$\mathrm{TNF} \alpha$ is an important pro-inflammatory cytokine mediating liver injury; its release from liver macrophages as shown from this study signifies a response to inflammation. The deleterious effect of IUGR on renal development is responsible for the risk of essential hypertension and kidney damage in adulthood; this agrees with results from our study ${ }^{37}$. Studies have demonstrated that TNF $\alpha$ confers an antioxidant imbalance which characterizes the beginning of various chronic 
diseases ${ }^{38}$. This further point to the increased risk of chronic inflammation of neonates of IUGR mothers which makes them susceptible to diseases in later life. Amarilyo et al. ${ }^{39}$ reported higher levels of TNF- $\alpha$ in the cord blood of IUGR infants, suggesting that a state of inflammation occurs in infants exposed to IUGR. In this study, GSH significantly reduced immunoreactivity of TNF $\alpha$ in the treated groups, especially in the group administered GSH on days 4-10. This agrees with the report of Rahman and MacNe ${ }^{40}$ who reported that GSH protects against free radical-mediated injury formed during inflammatory responses. Likewise, Galinier et al. ${ }^{41}$ demonstrated that chronic inflammatory diseases resorting from long term consequences of IUGR have been linked with reduced levels of GSH.

In conclusion, this study asserts the role of oral administration of GSH in regulating the inflammatory response in IUGR albeit at the early neonatal period; further studies will address the mechanisms involved to enhance the development of strategies to forestall the short and long term effects of IUGR in infants.

\section{Acknowledgment}

The authors hereby appreciate the International Brain Research Organization for funding this study.

\section{Declaration of interest}

There is no conflict of interest in this study.

\section{REFERENCES}

1. Hay WW, Thureen PJ, Anderson MS. Intrauterine growth restriction. NeoReviews. 2001; 2, 129-138. https://doi.org /10.1542/neo.2-6-e129.

2. Rosenberg A. The IUGR newborn. Sem. Perinatol. Philadelphia, PA, USA: Elsevier. 2008.

https://doi.org/10.1053/j.semperi.2007.11.003.

3. McMillen IC, Robinson JS. Developmental origins

of the metabolic syndrome: prediction, plasticity, and programming. Physiol. Rev. 2005; 85, 571633.

https://doi.org/10.1152/physrev.00053.2003.

4. Barker DJ, Meade TW, Fall CH et al. Relation of fetal and infant growth to plasma fibrinogen and factor VII concentrations in adult life. BMJ 1992; 304 , 148152. https://doi.org/10.1136/bmj.304.6820.148
5. Barker DJ, Marthyn CN, Osmond $\mathrm{C}$ et al. Growth in utero and serum cholesterol concentrations in adult life. BMJ 1993; 307, 1524

1527. https://doi.org/10.1136/bmj.307.6918.15 24.

6. Yajnik CS. Nutrient-mediated teratogenesis and fuelmediated teratogenesis: two pathways of intrauterine programming of diabetes. Int. J. Gynecol. Obstet. 2009; 104, 27-31. https://doi.org/10.1016/j.ijgo.2008.11.034.

7. Niu Y, He J, Ahmad H et al. Dietary Curcumin Supplementation Increases Antioxidant Capacity, Upregulates Nrf2 and Hmox1 Levels in the Liver of Piglet Model with Intrauterine Growth Retardation. Nutrients 2019; 11, 2978. https://doi.org/10.3390/nu11122978.

8. Cianfarani S, Agostoni C, Bedogni $\mathrm{G}$ et al. Effect of intrauterine growth retardation on liver and long-term metabolic risk. Int. J. Obesity 2012; 36, 1270-1277. https://doi.org/10.1038/ijo.2012.54.

9. Manalich R, Reyes L, Herrera, M et al. "Relationship between weight at birth and the number and size of renal glomeruli in humans: a histomorphometric

study," Kid. Int. 2000; 58, 770-773. https://doi.org/10.1046/j.1523-

1755.2000.00225.x.

10.Luyckx VA, Brenner BM et al. "Low birth weight, nephron number, and kidney disease," Kid. Int. Suppl. 2005; 68, 68-77. https://doi.org/10.1111/j.1523-

1755.2005.09712.x.

11. Teeninga N, Schreuder MF, Bokenkamp A et al. "Influence

of low birth weight on minimal change nephrotic syndrome in children, including a meta-analysis," Nephrol. Dial. Trans. 2008; 23, 16151620. https://doi.org/10.1093/ndt/gfm829.

12. Ogata ES, Swanson SL, Collins JW et al. Intrauterine growth retardation: altered hepatic energy and redox states in the fetal rat. Pediatr. Res. 1990; 27, 56-63. https://doi.org/10.1203/00006450-19900100000017 .

13.Lane RH, Flozak AS, Ogata ES et al. Altered hepatic gene expression of enzymes involved in energy metabolism in the growth-retarded fetal rat. Pediatr. Res. 1996; 39, 390-394. 
https://doi.org/10.1203/00006450-19960300000003.

14.Lane RH, Crawford SE, Flozak AS et al. Localization and quantification of glucose transporters in liver of growth-retarded fetal and neonatal rats. Am. J. Physiol. 1999; 276, 135142. https://doi.org/10.1152/ajpendo.1999.276.1.E1 35.

15.Smith CV, Hansen JN, Martin NE et al. Oxidant stress

responses in premature infants during exposure to

hyperoxia.

Pediatr. Res. 1993; 34, 360-36. https://doi.org/10.1203/00006450-19930900000024.

16. Biri A, Bozkurt N, Turp A et al. Role of oxidative stress in intrauterine growth restriction. Gynecol. Obstet. Investig. 2007; 64, 187-192. https://doi.org/10.1159/000106488.

17.Küster A, Tea I, Ferchaud-Roucher V et al. Cord blood glutathione depletion in preterm infants: correlation with maternal cysteine depletion. PLoS One. 2011;6(11), e27626. https://doi.org/10.1371/journal.pone.0027626.

18. Aquilano K, Baldelli S, Ciriol $\mathrm{MR}$ et al. Glutathione: New roles in redox signaling for an old Front. Pharmacol. 2011; 5, 196. https://doi.org/10.3389/fphar.2014.00196.

19.Espinosa-Diez C, Miguel V, Mennerich, D et al. Antioxidant responses and cellular adjustments to oxidative stress. Redox Biol. 2015; 6, 183197.

https://doi.org/10.1016/j.redox.2015.07.008.

20.Scirè L, Cianfruglia C, Minnelli $\mathrm{C}$ et al. Glutathione compartmentalization and its role in glutathionylation and other regulatory processes of cellular pathways. BioFactors Oxf. Engl. 2019; 45, 152-168. https://doi.org/10.1002/biof.1476.

21.Manna P, Jain SK. Obesity, oxidative stress, adipose

tissue dysfunction, and the associated health risks: causes and therapeutic strategies. Metab. Syndr. Relat. Disord. 2015; 13, 423-444. https://doi.org/10.1089/met.2015.0095.

22.Rani V, Deep G, Singh RK et al. Oxidative stress and metabolic disorders: pathogenesis and therapeutic strategies. Life Sci. 2016; 148, 183193. https://doi.org/10.1016/j.lfs.2016.02.002.

23.Akoumianakis I, Antoniades C. Impaired vascular redox signaling in the vascular complications of obesity and diabetes mellitus. Antioxid. Redox Signal 2019; 20; 30(3), 333-53. https://doi.org/10.1089/ars.2017.7421.

24.McPherson RA, Hardy G. Clinical and nutritional

benefits of cysteine-enriched protein supplements. Curr. Opin. Clin. Nutr. Metab. Care 2011; 14: 562-568. https://doi.org/.1097/MCO.0b013e32834c1780

25. Yin J, Ren W, Yang G et al. L-Cysteine metabolism and its nutritional implications, Mol. Nutr. Food. Res. 2016; 60, 134-146. https://doi.org/10.1002/mnfr.201500031.

26. Goodlett CR, Peterson SD et al. Sex differences in vulnerability to developmental spatial learning deficits induced by limited binge alcohol exposure in neonatal rats. Neurobiol. Learn. Memory. 1995; 64(3), 265-75.

27. Brocardo PS, Boehme F, Patten A et al. Anxiety-and depression-like behaviors are accompanied by an increase in oxidative stress in a rat model of fetal alcohol spectrum disorders: Protective effects of voluntary physical exercise. Neuropharmacol. 2012; 62(4), 1607-18.

28.Patten AR, Moller DJ, Graham J et al. Liquid diets reduce cell proliferation but not neurogenesis in the adult rat hippocampus. Neuroscience. 2013; 254, 173-84.

29.Wu G, Bazer FW, Datta $S$ et al. Intrauterine growth retardation in livestock: Implications, mechanisms and solutions. Arch. fur Tierz. Arch. Anim. Breed. 2008; 51, 4-10.

30.Zohdi V, Lim K, Pearson JT et al. Developmental programming of cardiovascular disease following intrauterine growth restriction: Findings utilising a rat model of maternal protein restriction. Nutrients 2015; 7 , 119-152. https://doi.org/10.3390/nu7010119.

31.Black RE, Victora CG, Walker SP et al. Maternal and child undernutrition and overweight in low-income and middle-income countries. Lancet 2013; 382, 427-451. http://dx.doi.org/10.1016/S01406736(13)60937-X.

32.Xia Z, Wu S. Effects of glutathione on the survival, growth performance and non-specific 
immunity of white shrimps (Litopenaeus vannamei). Fish. Shellfish. immunol. 2018; 73, 141-4.

https://doi.org/10.1016/j.fsi.2017.12.015.

33. Sora T. Effects of combined glutathione and ursodeoxycholic acid therapy on chronic hepatitis C unresponsive to interferon. J. Med. Soc. Toho Univ. 2016; 45, 331-338.

34.Hussain T, Tan B, Yin Y et al. Oxidative Stress and Inflammation: What Polyphenols Can Do for Us?. Oxi. Med. Cellu. Long. 2016; 9. https://doi.org/10.1155/2016/7432797.

35. Kim YS, Young MR, Bobe $G$ et al. Bioactive food components, inflammatory targets, and cancer prevention. Cancer Prev. Res. 2009; 2, $200-$ 208. https://doi.org/10.1158/1940-6207.CAPR08-0141.

36. Hales C, Barker D. The thrifty phenotype hypothesis. Br. Med. Bull. 2001; 60, 5-20. https://doi.org/10.1093/bmb/60.1.5.

37.Bassan H, Trejo LL, Kariv $\mathrm{N}$ et al. Experimental intrauterine growth retardation alters renal development. Ped. Nephrol. 2000; 15(3-4):

192-5. https://doi.org/10.1007/s004670000457.

38.Jardine H, MacNee W, Donaldson $\mathrm{K}$ et al. Molecular mechanism of transforming growth factor (TGF)- $\beta 1$-induced glutathione depletion in alveolar epithelial cells involvement of AP1/ARE and Fra-1. J. Biol. Chem. 2002; 277, 21158-66. https://doi.org/1 0.1074/jbc.M112145200.

39. Amarilyo G, Oren A, Mimouni FB et al. "Increased cord serum inflammatory markers in small-for-gestational-age neonates," J. Perinatol. 2011; 31, 30-32. https://doi.org/10.1038/jp.2010.53.

40.Rahman I, MacNee W. Oxidative stress and regulation of glutathione in lung inflammation. Eur. Resp. J. 2000; 16, 534-554.

41.Galinier A, Carrière A et al. Adipose tissue proadipogenic redox changes in obesity. J. Biol. Chem. 2006; 281, 12682-12687. https://doi.org/10.1074/jbc.M506949200. 